\title{
LIMBAH INDUSTRI TEMPE RUMAHTANGGA SEBAGAI PUPUK DAN PAKAN TERNAK DI KELURAHAN PAKAL KECAMATAN PAKAL SURABAYA
}

\author{
Andri Krinadianto \\ Universitas Wijaya Putra \\ andrikrisna@uwp.ac.id
}

\begin{abstract}
Abstrak
Produksi tempe yang bahan dasarnya kedelai akan meninggalkan limbah. Sayangnya hingga saat ini belum banyak yang memanfaatkan limbah ini. Di kelurahan Pakal kecamatan Pakal, Surabaya, terdapat home industri pembuatan tempe. Jumlah pembuat tempe di Kelurahan Pakal ini kuranglebih berjumlah 20 orang, dan menghasilkan limbah cair kedelai sekitar 20 liter perhari, jika dikalkulasi jumlah limbah lebih dari 400 liter/hari. Dengan adanya hal ini, perlu inovasi agar limbah ini dapat lebih berdayaguna dan diharapkan dapat membantu perekonomian masyarakat. Kami mengajukan ide, limbah tempe ini diolah untuk campuran pakan ternak dan pupuk organic. Kegiatan yang akan dilakukan meliputi: sosialisasi, pelatihan dan pelaksanaan program pengolahan limbah cair tempe. Pengolahan ini diharapkan memberikan keuntungan bagi masyarakat Kelurahan Pakal secara materi dan masyarakat Kelurahan Pakal lebih sadar terhadap limbah tempe yang mereka produksi sekaligus dapat memanfaatkannya. Diharapkan pula nantinya masyarakat Kelurahan Pakal dapat memproduksi olahan limbah dan memasarkan ke masyarakat luas.
\end{abstract}

\section{Kata Kunci : tempe, limbah, industri}

\section{PENDAHULUAN}

Industri tempe rumah tangga merupakan industri mikro yang banyak dijumpai di masyarakat. Produksi tempe ini banyak dilakukan di daerah pemukiman penduduk. Namun, masih banyak yang belum memiliki sistem pengolahana limbah yang baik. Limbah cair yang diperoleh sebagai hasil sampingan pembuatan tempe jika tidak dikelola dengan baik dan hanya digunakan sebagai pakan ternak atau bahkan dibuang ke perairan akan sangat mengganggu lingkungan disekitarnya karena dapat merusak kualitas air tanah, mengakibatkan timbulnya bau tidak sedap, serta memicu tumbunya berbagai bakteri pathogen.

Proses produksi industri tempe menghasilkan limbah cair yang berasal dari lokasi pemasakan kedelai, pencucian kedelai, peralatan proses, serta lantai. Karakter limbah cair yang dihasilkan berupa bahan organic padatan tersuspensi (kulit, selaput lendir dan bahan organic lain). Salah satu pengolahan limbah cair rebusan kedelai adalah dengan menjadikannya pakan hewan ternak hewan dan pupuk organik. Berdasarkan data yang dirilisoleh www.pilnas.ristek.go.id air rebusan kedelai ternyata memiliki kandungan protein sebesar 5,29\%, lemak 0,54\%, air 72,08 \% dan abu $3,38 \%$.

Jumlah pembuat tempe di kelurahan Pakal ini kurang lebih berjumlah 20 orang, setiap pembuat tempe menghasilkan limbah cair kedelai sekitar 20 liter perhari. Selama ini limbah cair digunakan untuk pakan ternak yang dimiliki warga, jika dikalkulasi jumlah limbah ini berjumlah lebih dari 400 liter/hari. Dengan banyaknya jumlah limbah ini, dirasa perlu untuk membuat inovasi agar limbah ini dapat lebih berdayaguna dan diharapkan dapat membantu perekonomian masyarakat. Pengolahan Limbah Tempe di kelurahan Pakal diharapkan dapat menjadi salah satu solusi konkret guna mengatasi permasalahan tersebut. 
Berdasarkan pemaparan di atas, maka masalah yang ingin diselesaikan adalah sebagai berikut: Satu, Kurangnya kesadaran masyarakat di kawasan terhadap lingkungannya. Dua, Peningkatan pendapatan dan perekonomian masyarakat di kelurahan Pakal.

Tujuan dari diadakannya program ini yaitu: Satu, memberikan salah satu solusi kepada masyarakat dalam memanfaatkan limbah tempe. Dua, membentuk komunitas peduli lingkungan di kelurahan Pakal dalam upaya meningkatkan rasa sadar limbah antar warga setempat. Tiga, memberdayakan masyarakat dalam meningkatkan kreatifitas dan mengembangkan usaha mandiri dalam pengolahan limbah tempe sehingga menambah pendapatan bagi masyarakat itu sendiri.

Target yang diharapkan dari kegiatan ini yaitu: Satu, meningkatkan kesadaran masyarakat untuk menjaga kesehatan melalui pemanfaatan limbah tempe. Dua, terbentuknya suatu komunitas yang kreatif di kelurahan Pakal. Tiga, masyarakat mandiri melalui pengolahan limbah tempe.

Kegunaan yang diharapkan dari kegiatan ini yaitu: Satu, member pengetahuan dan pelatihan kepada masyarakat sasaran tentang pengolahan limbah tempe kedelai menjadi produk lain. Dua, untuk memberi pengetahuan dan pelatihan kepada masyarakat sasaran tentang pengolahan limbah tempe kedelai menjadi pupuk. Tiga, untuk member pengetahuan kepada masyarakat sasaran tentang penggunaan pupuk EM4 sebagaicampuran pakan ternak dan pupuk organik. Empat, memberdayakan masyarakat untuk menginovasikan hasil sisa yang berlebih

\section{METODE}

Metode yang akan dilaksanakan merupakan sebuah rangkaian tahapan yang disusun secara sistematis, diantaranya :

Satu, survei dan analisa kondisi lingkungan. Pada tahapan ini dilakukan survei terhadap kondisi lingkungan yang ada di kelurahan Pakal. Survei yang dilakukan meliputi survei tempat pembuatan tempe yang disertai dengan wawancara para pembuat tempe, Lurah dan pemuda karang taruna terhadap permasalahan limbah tempe yang ada di kelurahan Pakal sehingga didapatkan analisa terhadap permasalahan tersebut.
Dua, sosialisasi kepada masyarakat. Pada tahapan ini sosialisasi dilakukan pada masyarakat desa khususnya pada produsen tempe mengenai pentingnya pengembangan pengolahan limbah tempe yang berdayaguna bagi masyarakat desa. Sosialisasi ini dilaksanakan di kelurahan Pakal dengan mengajak seluruh elemen masyarakat yang ada di kelurahan Pakal.

Tiga, bekerja sama dengan pemuda karang taruna. Kami melakukan kerjasama dalam pelaksanaan rangkaian kegiatan pengembangan pengolahan limbah tempe dengan pemuda karang taruna kelurahan Pakal. Pemuda karang taruna yang merupakan golongan muda di kelurahan Pakal kami ajak untuk menjadi pelopor program pengembangan limbah tempe sebagai salah satu upaya peningkatan nilai jual dan dayaguna limbah tempe sebagai produk yang berninlai jual tinggi. Nantinya kelompok pemuda inilah yang akan memonitoring secara intensif dalam pelaksaan program ini.

Empat, pelatihan pengolahan limbah cair tempe. Pelatihan ini dilaksanakan di kelurahan Pakal dengan peserta pelatihan adalah masyarakat, produsen tempe dan pemuda karang taruna kelurahan Pakal. Kegiatan ini berisi demonstrasi pembiakkan EM4 yang berasal dari limbah cair tempe.

Lima, pelaksanaan program pengolahan limbah tempe. Kegiatan inti yang merupakan hasil dari serangkaian tahapan diatas, yang nantinya diharapkan mampu memberikan dampak positif bagi masyarakat di kelurahan Pakal. Pelaksanaan program ini hampir sama seperti saat pelatihan pengolahan limbah, namun setiap pengolahan yang dilakukan harus di dampingi oleh pemuda karang taruna kelurahan Pakal sehingga dapat di kontrol dan di monitoring dengan baik. Setiap pengolahannya juga dibukukan dan diharapkan dapat memberikan manfaat perekonomian bagi masyarakat desa.

\section{HASIL DAN PEMBAHASAN}

\section{Pupuk Organik Cair}

Pupuk organik merupakan pupuk dengan bahan dasar yang diambil dari alam dengan jumlah dan jenis unsur hara yang terkandung secara alami. 
Dapat dikatakan bahwa pupuk organik merupakan salah satu bahan yang sangat penting dalam upaya memperbaiki kesuburan tanah secara aman, dalam arti produk pertanian yang dihasilkan terbebas dari bahan-bahan kimia yang berbahaya bagi kesehatan manusia sehingga aman dikonsumsi (Huda, 2013).

Samekto (2008) dan Yuliarti (2009), mengemukakan bahwa pupuk organik merupakan hasil akhir dari peruraian bagian - bagian atau sisa -sisa tanaman dan binatang (makhluk hidup) misalnya pupuk kandang, pupuk hijau, kompos, bungkil, guano, tepung tulang dan lain sebagainya. Pupuk organik mampu menggemburkan lapisan permukaan tanah (top soil), meningkatkan populasi jasad renik, mempertinggi daya serap dan daya simpan air, yang oleh karenanya kesuburan tanah menjadi meningkat (Samekto, 2008).

Hal ini sependapat dengan Yuliarti (2009) penggunaan pupuk organik memberikan manfaat meningkatkan ketersediaan anion-anion utama untuk pertumbuhan tanaman seperti nitrat, fosfat, sulfat, borat, dan klorida, meningkatkan ketersediaan hara mikro untuk kebutuhan tanaman, dan memperbaiki sifat fisika, kimia, dan biologi tanah. Standar kualitas unsur makro pupuk organik berdasarkan Peraturan Menteri Pertanian No.28/SNI/Permentan/OT.140/2/2009 dapat di lihat pada tabel di bawah ini:

Tabel 4 Standart mutu pupuk organik cair (POC)

\begin{tabular}{|c|c|c|c|}
\hline Parameter & Satuan & $\begin{array}{c}\text { Persyaratan } \\
\text { Teknis }\end{array}$ & Keterangan \\
\hline C-organik & $\%$ & $>=4$ & $\begin{array}{l}\text { kandungan c-organik } \\
\text { jika }>2 \% \text { diduga }\end{array}$ \\
\hline $\mathrm{N}, \mathrm{P}, \mathrm{K}$ & $\%$ & $<2$ & $\begin{array}{l}\text { sudah mengandung } \\
\text { kimia anorganik }\end{array}$ \\
\hline Patogen & $\mathrm{cfu} / \mathrm{g}$ & $<102$ & $\begin{array}{l}\text { salmonela harus negatif } \\
\text { karena tingkat } \\
\text { bahayanya }\end{array}$ \\
\hline \begin{tabular}{|l|} 
Mikroba \\
Fungsional
\end{tabular} & $\mathrm{cfu} / \mathrm{g}$ & - & tingkat keaktifan bakteri \\
\hline $\mathrm{pH}$ & - & $4-8$ & $\begin{array}{l}\mathrm{pH} \text { yang terlalu } \\
\text { asam/basa tidak baik } \\
\text { untuk tanah }\end{array}$ \\
\hline
\end{tabular}

Menurut Sutejo (1994), kandungan unsur hara urine yang dihasilkan ternak tergantung mudah atau sukarnya makanan dalam perut hewan dapat dicernakan. Beliau juga menyatakan bahwa urine pada ternak sapi terdiri dari air 92\%, N 1,00\%, P 0,2 $\%$,dan $\mathrm{K} 1,35 \%$. Berdasarkan data di atas maka urine sapi termasuk dalam bahan dasar yang bisa dijadikan pupuk organik cair.

\section{Proses Pembuatan Pupuk Organik Cair}

- Alat:

1. Tong atau drum

2. Ember

3. Pengaduk

- Bahan:

1. Limbah tempe cair

2. Molasses

3. Larutan EM4

4. Air

- Proses Pembuatan pupuk organik cair, dengan tahapan kegiatan sebagai berikut:

Pertama, masukkan limbah tempe, larutan EM4, air, dan molasses ke dalam drum.

Kedua, aduk hingga tercampur merata, kemudian tutup rapat dan diamkan selama satu minggu.

Kedua, Pasang label pada drum atau tong yang digunakan untuk mengolah pupuk organic cair. Label berfungsi sebagai penanda waktu kapan pupuk mulai dibuat dan kapan bisa digunakan.

Tingkat kematangan pupuk organik cair dapat diidentifikasi dari hilangnya bau pada pupuk orgnaik cair tersebut. Proses pengolahan yang baik dan benar akan menghasilkan pupuk organik cair yang tidak panas, tidak berbau busuk, tidak mengandung hama dan penyakit, serta tidak membahayakan pertumbuhan ataupun produksi tanaman. Jika dilakukan dengan benar, pupuk cair akan mencapai kematangan sekitar 4-7 hari setelah pembuatan. Pupuk cair digunakan dengan cara mencampurkannya dengan air.

\section{Manfaat Pupuk Organik Cair}

Pupuk organik cair mempunyai beberapa manfaat diantaranya adalah :

Satu, dapat mendorong dan meningkatkan pembentukan klorofil daun dan pembentukan bintil akar pada tanaman leguminosae sehingga meningkatkan kemampuan fotosintesis tanaman dan penyerapan nitrogen dari udara.

Dua, dapat meningkatkan vigor tanaman sehingga tanaman menjadi kokoh dan kuat, meningkatkan 
daya tahan tanaman terhadap kekeringan, cekaman cuaca dan serangan patogen penyebab penyakit. Tiga, merangsang pertumbuhan cabang produksi. Empat, meningkatkan pembentukan bunga dan bakal buah, serta

Lima, mengurangi gugurnya daun, bunga dan bakal buah.

Pemberian pupuk organik cair harus memperhatikan konsentrasi atau dosis yang diaplikasikan terhadap tanaman. Berdasarkan beberapa hasil penelitian menunjukkan bahwa pemberian pupuk organik cair melalui daun memberikan pertumbuhan dan hasil tanaman yang lebih baik daripada pemberian melalui tanah.

Semakin tinggi dosis pupuk yang diberikan maka kandungan unsur hara yang diterima oleh tanaman akan semakin tinggi, begitu pula dengan semakin seringnya frekuensi aplikasi pupuk daun yang dilakukan pada tanaman, maka kandungan unsur hara juga semakin tinggi. Namun, pemberian dengan dosis yang berlebihan justru akan mengakibatkan timbulnya gejala kelayuan pada tanaman.

\section{Kelebihan dan Kekurangan Pupuk Organik Cair}

Adapun keunggulan dari pupuk organik cair yaitu :

Satu, mudah untuk membuatnya

Dua, murah harganya

Tiga, tidak ada efek samping bagi lingkungan maupun tanaman

Empat, bisa juga dimanfaatkan untuk mengendalikan hama pada daun (bio-control), seperti ulat pada tanaman sayuran

Lima, aman karena tidak meninggalkan residu, pestisida organik juga tidak mencemari lingkungan.

Kelemahan yang umum terdapat pada pupuk organik/ hayati cair, yaitu :

Pertama, viabilitas (daya hidup) mikroorganisme yang dikandungnya sangat rendah

Kedua, populasi mikroorganisme kecil $(<106$ $\mathrm{cfu} / \mathrm{mL}$ ), bahkan cenderung tidak ada/mati seiring dengan waktu

Ketiga, nutrisi yang terkandung sedikit. Umumnya nutrisi yang ada berupa tambahan bahan kimia seperti pupuk NPK dan Urea

Keempat, mikroorganisme di dalamnya sangat mudah berkurang bahkan mati
Kelima, tingkat kontaminasi sangat tinggi

Keenam, seringkali menghasilkan gas (kemasan rusak) dan bau tidak sedap (busuk)

Ketujuh, Tidak tahan lama (kurang dari setahun)

Kedelapan, Masalah dalam transportasi dan penyimpanan

Kesembilan, Perlu ketekunan dan kesabaran yang tinggi dalam membuatnya

Kesepuluh, Hasilnya tidak bisa diproduksi secara asal.

\section{Pengaplikasian Pupuk Organik Cair}

Penggunaan pupuk organik padatan sebaiknya dibarengi dengan penggunaan pupuk organik cair. Nutrisi yang terkandung pada POC akan lebih mudah diserap oleh tanaman. POC akan lebih efektif dan efisien bila dipalikasikan pada daun, bunga dan batang, dibandingkan dengan media tanam kecuali untuk metode hidroponik. POC berperan pula sebagai perangsang tumbuh, terutama saat tanaman berasa pada peralihan fase vegetatif ke generatif atau saat tumbuhan mulai bertunas. Memberikan POC melalui bagian daun atau batang akan memudahkan tanaman menyerapnya melalui pori-pori atau stomata pada daun.

Setiap bagian tanaman memiliki kapasitas yang berbeda-beda saat menyerap nutrisi yang tersedia. Umumnya, tanaman hanya mampu menyerap sekitar $2 \%$ unsur hara setiap harinya, seperti kapasitas yang diperkirakan dimiliki oleh daun. Karenanya, menggunakan POC akan lebih efektif bila digunakan. Untuk mencegah pemberian berlebih atau nutrisi yang overdosis bagi tanaman, POC dapat dibuat encer, dan tidak lebih dari $2 \%$. Untuk membuatnya encer, dapat dilakukan pengenceran seratus kali yang berarti bahwa 1 liter pupuk diencerkan pada 100 liter AIR. Perbandingan 1 : 100 yang akan menghasilkan persentasi $1 \%$ tersebut dapat disesuaikan dengan kebutuhan/volume POC yang dibutuhkan. Bila hanya membutuhkan 1 liter POC, maka dapat dibuat dengan melarutkan air bersama dengan 0.25 liter pupuk.

Bila POC ditujukan untuk menutrisi pertumbuhan daun, maka untuk pengaplikasiannya dapat dilakukan dengan menyemprotkan pada tanaman yang baru bertunas. Namun, bila ditujukan 
untuk memaksimalkan pertumbuhan buah, biji atau umbi, maka aplikasikan pada saat peralihan fase vegetatif ke generatif. POC dapat disemprotkan langsung pada bagian bunga, buah atau daun dengan interval waktu pengaplikasian sekitar seminggu sekali pada musim kering atau 3 hari sekali pada musim hujan.

\section{Evaluasi Hasil Pelaksanaan}

Tim pelaksana pengabdian di kelurahan Pakal menemukan beberapa kendala oleh masyarakat khususnya kelompok pengolah tempe sepak terjang bahwa masih kurangnya pemanfaatan dan pengolahan limbah sebagai pupuk organik, khususnya limbah tempe.

Pemberian materi pelatihan dengan metode ceramah, demonstrasi dan eksperimen. Metode ceramah dilakukan dengan cara pemberian teori tentang pemanfaatan limbah tempe untuk pembuatan pupuk organik cair yang dilakukan di salah satu rumah penduduk kelurahan pakal. Setelah selesai pemberian teori dilanjutkan dengan demonstrasi pembuatan pupuk organik cair yang digunakan sebagai pupuk alternative yang dapat memperbaiki unsur hara tanah.

Dari semua materi yang diberikan masyarakat menyambutnya dengan antusias hal ini terbukti dengan banyaknya pertanyaan yang diajukan kepada pemateri, berarti dengan kata lain memberikan respon positif terhadap materi yang diberikan.

\section{Evaluasi Hasil Pembuatan Pupuk Organik Cair}

Penilaian dari hasil pembuatan pupuk organik cair yang dibuat saat melakukan eksperimen menunjukkan hasil yang bagus. Hal ini terbukti dari tidak adanya bau yang menyengat pada pupuk organik cair tersebut dan tanaman yang diberikan pupuk tersebut daunnya semakin hijau dan mengalami pertumbuhan yang cepat disbanding tanaman yang tidak diberikan pupuk organik cair.

\section{KESIMPULAN}

Pelatihan pembuatan pupuk organik cair dari limbah tempe sebagai pupuk organik berhasil dengan baik, hal ini dengan antusiasinya masyarakat untuk mengikuti pelatihan serta adanya respon tanya jawab.

Masyarakat kelurahan Pakal mendapat pengetahuan baru tentang pemanfaatan limbah tempe sebagai bahan pembuatan pupuk organik cair, hal ini juga didukung dengan banyaknya ternak yang dimiliki oleh masyarakat sehingga banyak pula limbah tempe yang dihasilkan dan sudah dapat dimanfaatkan.

Pupuk organik cair yang dihasilkan sangat bagus, hal ini terlihat dari tidak adanya bau yang menyengat pada pupuk organik cair tersebut dan tanaman yang diberikan pupuk organik tersebut mengalami pertumbuhan yang cepat.

Saran yang di berikan adalah pengaplikasian pupuk organik cair harus memperhatikan waktu pemberian dan dosis yang digunakan.

\section{UCAPAN TERIMAKASIH (Bila ada)}

Ucapan terimakasih disampaikan kepada Universitas Wijaya Putra yang telah memberikan kontribusi dalam pelaksanaan kegiatan.

Ucapan terima kasih disampaikan kepada LPPM

Universitas Wijaya Putra yang telah mengarahkan memfasilitasi PKM ini.

\section{REFERENSI}

Huda M K. 2013. Pembuatan Pupuk Organik Cair Dari Urin Sapi Dengan Aditif Tetes Tebu (Molasses) Metode Fermentasi. Skripsi. Universitas Negeri Semarang.

Samekto Riyo. 2008. Pemupukan .Yogyakarta :PT.Aji Cipta Pratama.

Yuliarti Nugraheti.2009.1001 Cara

Menghasilkan Pupuk Organik .Yogyakarta :Lily Publisher. 